\title{
Supply Chain Risk Management: An Approach to Reduce The Agricultural Product's Logistics Costs
}

\author{
Adi Djoko Guritno \\ Department of Agroindustrial Technology, Faculty of Agricultural Technology \\ Universitas Gadjah Mada, Jl. Flora No.1 Bulaksumur 55281, Indonesia. \\ Email: adidjoko@tip-ugm.org
}

\begin{abstract}
Characteristics of perishable agricultural products led to an expensive logistics costs and the need for specific treatment along the supply chain to the consumer. The differences in treatment as well as the acceptance of risk in each tier supply chain lead to different ways of mitigating the risk. The use of the combination method of risk management and supply chain management can be done to improve the performance supply chain. By reducing the potential risk the possibility of damage due to transportation and distribution can be reduced. Results of the research have been done in some cases (corn and fresh vegetables) and combined with fulfillment of inventory by the service level that occurs is an alternative to reduce the logistics cost.
\end{abstract}

Keywords: perishable, ISO 31000, risk mitigation, supply chain, logistics cost

\section{INTRODUCTION}

Risks are things that resulted in a loss in terms of both quality and quantity. The existence of these risks will lead to the objectives cannot be realized due to a decline in quality and quantity. If this happens then the vegetables advantage in the face of the competitive situation cannot be achieved. The risks that exist in the supply chain of agricultural commodities differ from the risks to the supply chain of industrial products as well as the risk to the institution. Risk in agricultural commodities has wider complexities such as the effect of changes in the weather, natural disasters, biological and environmental factors (Guritno et al., 2013).

The development of risk management includes the development of dashboards that can be used for monitoring, feed-back management, control and prevention as well as guidance on the implementation of the farm, the perception of the regulations concerned, the benefit of economics, analyzes financially as well as analysis of the impact that occurred (Guritno $^{1}$, 2013). The focus of risk management shall be directed to factors: risk register, risk maps and risk notifications. While the level of analysis and risk management will be developed on the factors: Key Risk
Indicator (KRI), risk mitigation and Key Control Indicators (Jaffee et al., 2010).

Supply chain risk management (CRM) is a structure and process integration to optimize the strategy, processes, human resources, and technology. Supply chain risk management is the combination of supply chain management and risk management. In this study, the risk assessment process is based on ISO 31000 . ISO 31000 standard chosen because it is a principle and guidelines for managing various risks systematically that can be used for various spheres and contexts. Logistics costs structure analysis aims to determine the proportion of logistics costs and determine the activities that can be controlled. Research on logistics costs (Pishvaee et al, 2009).

\section{METHODS}

The data that have been collected was processed and analyzed qualitatively. Qualitative risk analysis follows the ISO 31000 standard risk: 2009. According to Purdy (2010), there are some standards that developed on risk management, such as COSO ERM and ASN / NZS 4360: 2004, which has been combined with the ISO standard into the ISO 31000: 2009. Next will be produced vegetable matrix commodity risk by 
implementing Rapid Agricultural Supply Chain Risk Assessment (RapAgRisk). Risk matrix is a reference in the prevention, treatment, and control of risks. Logistics analysis conducted on all tiers in the supply chain.

\section{Case 1: Agricultural Risk Mitigation of Mycotoxin on Corn}

This study focused on the negative impact of mycotoxin on corn that provide short-term losses and long-term from the farmer to the
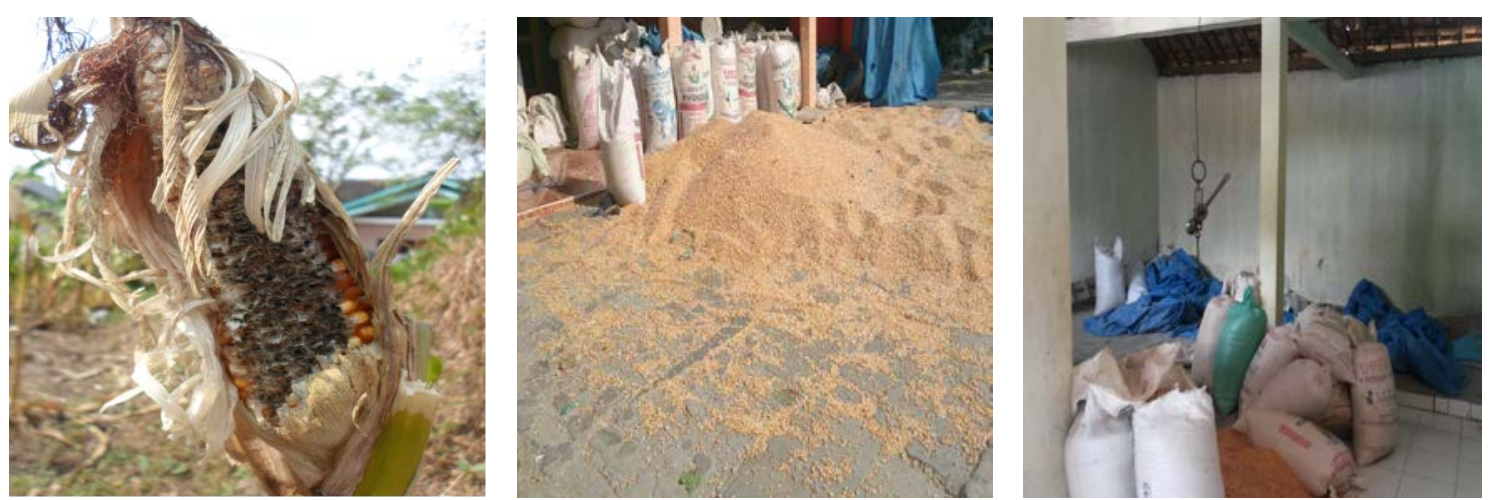

Fig 1. Source of mycotoxin from the cornfield, natural drying process, and storage (left to right side).

\section{RESULT AND DISCUSSION}

According to Waters (2007), the risk in supply chain management, known as Supply Chain Risk Management (SCRM) is an event that does not look exactly so that when the event occurs it will disrupt the smooth flow of material. Judging from the view of the risks, risks that arise in one part of the supply chain can be transferred to this part of the supply chain other because each component in the supply chain related to each other. Kusumaputri et al. (2012) states the risk in supply chain management can occur in many different variations, where the risk can arise due to external and internal factors, affecting the long-term and short-term, give a small impact even have a major impact, and some risks may occur in the intensity of the routine even rarer occurred but have a major impact as the risk of natural disasters. Risk is never constant but instead arises and changes over time, which means that risk management is a process that will continue so that the necessary control (monitoring) of the existing risks so that mitigation can be implemented properly given (Waters, 2007). consumer. To minimize the impact of the necessary efforts to understand the amount of risk at all levels of the supply chain and map out every risk, so as to formulate risks, mitigation services to every level of the supply chain commodities. With the elaboration of the risk analysis and logistics costs structure analysis in this study, is expected to be a reference in controlling the negative effects of mycotoxin in corn so as to minimize the risk of mycotoxin and logistics costs can be controlled.

Activities that need to be prioritized is the pre-harvest activity with regard corn skin conditions and the presence of pests. As shown in Figure 1, corn skin conditions that cannot be shut down completely corncob an initial trigger fungal infections. According Rahayu et al. (2003), corn cob husks that are not completely closed the way for the entry of pests (Heliothis, Sithopillus) adults to lay their eggs on grain corn kernels and then hatch, becoming larvae breed and feed on corn kernels. Injuries to the corn grain will trigger the A. flavus infection. 
Tabel 1. Risk mitigation dan risk treatment of corn.

\begin{tabular}{|c|c|c|c|c|}
\hline \multirow{2}{*}{ Tier } & \multicolumn{2}{|c|}{ Parameter } & \multirow{2}{*}{ Risk Mitigation } & \multirow{2}{*}{ Risk Treatment } \\
\hline & No & Risk & & \\
\hline \multirow{6}{*}{$\begin{array}{c}\text { TIER } 1 \\
\text { (Farmer) }\end{array}$} & 1 & $\begin{array}{l}\text { Corn skin } \\
\text { condition }\end{array}$ & $\begin{array}{l}\text { Treatment plants regularly by taking into } \\
\text { account the intensity of irrigation. In } \\
\text { addition, variations in seed selection is } \\
\text { necessary in order not always to plant hybrid } \\
\text { seeds. }\end{array}$ & $\begin{array}{l}\text { Harvesting the corn husks conditions have } \\
\text { been open. Protecting corn open klobotnya } \\
\text { conditions to reduce the initial trigger }\end{array}$ \\
\hline & 2 & Insect & Spraying pesticides or pesticide periodically & $\begin{array}{l}\text { Eliminating the affected corn pests and } \\
\text { eradicate so as not to spread }\end{array}$ \\
\hline & 3 & Drying time & $\begin{array}{l}\text { Separating drying corn semiarid with a new } \\
\text { one will be drained }\end{array}$ & $\begin{array}{l}\text { Sorting to separate the corn ready for sale } \\
\text { (dry) with corn that still need to be dried } \\
\text { again }\end{array}$ \\
\hline & 4 & $\begin{array}{l}\text { Peeling } \\
\text { method }\end{array}$ & $\begin{array}{l}\text { Fertilization is done manually (Conventional } \\
\text { tools) to minimize the number of agencies } \\
\text { and the injured corn cob corn shipped }\end{array}$ & $\begin{array}{l}\text { Sorting and grading is done to separate the } \\
\text { cobs are shipped back and a broken } \\
\text { institution. }\end{array}$ \\
\hline & 5 & $\begin{array}{l}\text { Storage } \\
\text { condition }\end{array}$ & $\begin{array}{l}\text { Minimizing the amount of corn that is stored } \\
\text { in a manner timely harvest and immediately } \\
\text { sold }\end{array}$ & $\begin{array}{l}\text { Given the pedestal so as not to directly } \\
\text { touch the floor }\end{array}$ \\
\hline & 6 & Storage time & Sold immediately after harvest & $\begin{array}{l}\text { Ensuring corn completely dry when stored } \\
\text { in sacks }\end{array}$ \\
\hline \multirow{5}{*}{$\begin{array}{c}\text { TIER } 2 \\
\text { (Collector) }\end{array}$} & 1 & $\begin{array}{l}\text { Drought } \\
\text { checking }\end{array}$ & Checking the corn drought before buying & $\begin{array}{l}\text { Sorting and drying repeated if there is corn } \\
\text { that has not dried }\end{array}$ \\
\hline & 2 & Storage time & $\begin{array}{l}\text { Saving with dryness }<12 \% \text { or store within }< \\
3 \text { months so that the risk can be reduced } \\
\text { moldy }\end{array}$ & $\begin{array}{l}\text { Giving reasons that are not directly touch } \\
\text { the floor. Conduct periodic inspections to } \\
\text { prevent the spread of fungal mycotoxin } \\
\text { Can also be done with immediate sales }\end{array}$ \\
\hline & 3 & $\begin{array}{l}\text { Storage } \\
\text { condition }\end{array}$ & $\begin{array}{l}\text { Reduce the time to save and immediately } \\
\text { make a sale }\end{array}$ & $\begin{array}{l}\text { Giving reasons that are not directly } \\
\text { affected by the floor, pay attention to the } \\
\text { barn air circulation }\end{array}$ \\
\hline & 4 & $\begin{array}{l}\text { Transportatio } \\
\text { n risk }\end{array}$ & Shortened transportation time & Noting air circulation \\
\hline & 5 & No sortation & $\begin{array}{l}\text { Selecting or choosing the time of purchase of } \\
\text { the previous tier }\end{array}$ & $\begin{array}{l}\text { Separation before saving or checking the } \\
\text { current sale. }\end{array}$ \\
\hline \multirow{3}{*}{$\begin{array}{l}\text { TIER } 3 \\
\text { (Trader) }\end{array}$} & 1 & Storage time & $\begin{array}{l}\text { Doing the purchase agreement with the } \\
\text { consumer and with the previous tier, so as to } \\
\text { minimize the amount of corn stored }\end{array}$ & $\begin{array}{l}\text { Drying over until the moisture content } \\
<12 \% \text { before storage, regulating entry and } \\
\text { exit of goods, checking periodically }\end{array}$ \\
\hline & 2 & Drought level & Checking the drought before the transaction & $\begin{array}{l}\text { Sorting and drying repeated if there is corn } \\
\text { that has not been dried. Splitting the } \\
\text { handling of corn that have been } \\
\text { standardized and are not }\end{array}$ \\
\hline & 3 & $\begin{array}{l}\text { Storage } \\
\text { condition }\end{array}$ & Immediate sales & $\begin{array}{l}\text { To control the condition and give } \\
\text { antifungal medications or fumigant }\end{array}$ \\
\hline \multirow{3}{*}{$\begin{array}{c}\text { TIER } 4 \\
\text { (Consumer) }\end{array}$} & 1 & Storage time & $\begin{array}{l}\text { Immediately conduct toward corn } \\
\text { consumption and purchase in intensity that } \\
\text { often, but the number is not too large }\end{array}$ & $\begin{array}{l}\text { Checking the water content so it can be } \\
\text { estimated maximum storage time }\end{array}$ \\
\hline & 2 & Drought level & $\begin{array}{l}\text { Checking drought corn before buying and } \\
\text { buying of parties that can meet the standards } \\
\text { that have been set }\end{array}$ & Sorting and drying again \\
\hline & 3 & $\begin{array}{l}\text { Storage } \\
\text { condition }\end{array}$ & $\begin{array}{l}\text { Accelerate the turnover of goods in order not } \\
\text { to keep the number of efficient }\end{array}$ & Corn condition checked regularly \\
\hline
\end{tabular}

An indicator of the presence of mycotoxin in corn and peanuts can be classified into two indicators are indicators of descriptive and visual indicators. The following descriptive indicators which can be a trigger and driver of the mycotoxin grows in each tier. Furthermore, in practice sales from wholesalers to the animal feed industry, can be identified efforts to reduce the risks to the presence of mold and other triggering factors, especially moisture. The size and weight reduction of the penalty imposed by the animal feed industry is known as refraction. Here is shown the value of refraction for corn comes from a wholesaler to the animal feed industry.

Based on the calculation of the data processed, it is known the percentage of each activity at each tier logistics. In Table 2, it is known that at each tier, namely farmers, wholesalers and traders, the largest logistics costs contained in material handling activities. At the level of farmers and traders, the cost is also quite high percentage contained in the transport activity. While at the level of the other dominant collectors percentage contained in the storage activity reached 20\%. This shows that the material handling logistics is the 
most dominant activity and has the highest proportion of the cost of the entire logistics costs, even at any tier that have logistics costs.

\section{Case 2: Supply Chain Risk Management of Fresh Vegetables}

The focus of the study was to analyze the supply chain and identifying the risks that exist at every level (tier) in the supply chain from
From risk mapping results will be obtained information on the risk priority, scale capacity to handle risk, vulnerability to risks that can be divided into strategic ex-ante and ex-post to handle risks in the supply chain based on time and will result in risk mitigation. Besides information about the cost structure is also used as the basis of risk analysis and risk mitigation manufacture.

Logistics costs, including procurement,

Table 2. The logistics cost percentage of each corn tier.

\begin{tabular}{|c|c|c|c|c|c|c|}
\hline Tier & $\begin{array}{c}\text { Procurement } \\
(\mathbf{\% )}\end{array}$ & $\begin{array}{c}\text { M. Handling } \\
\mathbf{( \% )}\end{array}$ & $\begin{array}{c}\text { Maintenance } \\
\mathbf{( \% )}\end{array}$ & $\begin{array}{c}\text { Inventory } \\
\mathbf{( \% )}\end{array}$ & $\begin{array}{c}\text { Transportation } \\
\mathbf{( \% )}\end{array}$ & $\begin{array}{c}\text { Information } \\
(\mathbf{\%})\end{array}$ \\
\hline Farmer & 32.62 & 73.24 & 58.76 & 33.10 & 50.49 & 41.02 \\
\hline Collector & 24.93 & 8.90 & 18.63 & 28.94 & 13.32 & 12.64 \\
\hline Trader & 42.44 & 17.86 & 22.61 & 37.96 & 36.19 & 46.34 \\
\hline Total (\%) & $\mathbf{1 0 0 . 0 0}$ & $\mathbf{1 0 0 . 0 0}$ & $\mathbf{1 0 0 . 0 0}$ & $\mathbf{1 0 0 . 0 0}$ & $\mathbf{1 0 0 . 0 0}$ & $\mathbf{1 0 0 . 0 0}$ \\
\hline
\end{tabular}

Table 3. The cost percentage of logistics activities in each corn tier.

\begin{tabular}{|c|c|c|c|c|c|c|c|}
\hline Tier & $\begin{array}{c}\text { Procurement } \\
(\%)\end{array}$ & $\begin{array}{c}\text { M. Handling } \\
\text { (\%) }\end{array}$ & $\begin{array}{c}\text { Maintenance } \\
\text { (\%) }\end{array}$ & $\begin{array}{l}\text { Inventory } \\
\text { (\%) }\end{array}$ & $\begin{array}{c}\text { Transportation } \\
\text { (\%) }\end{array}$ & $\begin{array}{c}\text { Information } \\
(\%)\end{array}$ & Total (\%) \\
\hline Farmer & 1.23 & 76.27 & 4.68 & 4.64 & 12.68 & 0.50 & 100.00 \\
\hline Collector & 4.89 & 48.15 & 7.70 & 21.07 & 17.39 & 0.80 & 100.00 \\
\hline Trader & 4.33 & 50.31 & 4.87 & 14.38 & 24.58 & 1.53 & 100.00 \\
\hline
\end{tabular}

farmers, wholesalers, suppliers, up to the end users. The information comes from the owner of the risk. In addition, there are also aspects of logistics costs can be a supporter of research information. material handling, maintenance, inventory, transportation, and information on each tier and then calculated the average in units of $\mathrm{Rp} / \mathrm{kg}$. Thus obtained proportion of each activity to the overall logistics costs. Supply

Tabel 4. Risk parameters of organic and non-organic vegetables.

\begin{tabular}{|c|c|c|c|}
\hline Tier & $\begin{array}{l}\text { Risk } \\
\text { Code }\end{array}$ & Parameter & Description \\
\hline \multirow{4}{*}{$\begin{array}{l}\text { TIER } 1 \\
\text { (Farmer) }\end{array}$} & R.1.1 & $\begin{array}{l}\text { Changes in rainfall } \\
\text { intensity }\end{array}$ & $\begin{array}{l}\text { High rainfall will damage the leaves of vegetables and vegetable fruit } \\
\text { will quickly rot while low rainfall can reduce yields of vegetables }\end{array}$ \\
\hline & R.1.2 & $\begin{array}{l}\text { The existence of } \\
\text { plant diseases }\end{array}$ & $\begin{array}{l}\text { The existence of pests and plant diseases can cause crops to fail or } \\
\text { degrade the quality of vegetable crops }\end{array}$ \\
\hline & R.1.3 & $\begin{array}{l}\text { Eruption of Merapi } \\
\text { mountain }\end{array}$ & $\begin{array}{l}\text { Ash from Merapi mountain can damage vegetables and very thick ash } \\
\text { that may inhibit the process of photosynthesis to harvest a total failure } \\
\text { and had to start from scratch again venture capital. }\end{array}$ \\
\hline & R.1.4 & $\begin{array}{l}\text { Vegetable damages } \\
\text { in field }\end{array}$ & $\begin{array}{l}\text { Handling while in the land greatly affect the harvest of vegetables. } \\
\text { Application of fertilizers, irrigation, and planting patterns should be } \\
\text { better. }\end{array}$ \\
\hline \multirow{4}{*}{$\begin{array}{l}\text { TIER } 2 \\
\text { (Collector) }\end{array}$} & R.2.1 & Demand changes & $\begin{array}{l}\text { Inventory must be provided changeable so it must communicate with } \\
\text { farmers and suppliers. }\end{array}$ \\
\hline & R.2.2 & $\begin{array}{l}\text { Damages in } \\
\text { transportation }\end{array}$ & $\begin{array}{l}\text { Accidents that may occur during transmission can be a risk for workers } \\
\text { and also vegetables. }\end{array}$ \\
\hline & R.2.3 & Retour product & $\begin{array}{l}\text { There are collectors who do consignment system so that when it is } \\
\text { returned by the supplier should be able to look for other markets. }\end{array}$ \\
\hline & R.2.4 & Price changes & $\begin{array}{l}\text { Change in the price of farmers occurred before the collectors do a deal } \\
\text { with a supplier. }\end{array}$ \\
\hline \multirow{5}{*}{$\begin{array}{l}\text { TIER } 3 \\
\text { (Trader) }\end{array}$} & R.3.1 & $\begin{array}{l}\text { Transportation to } \\
\text { modern trade }\end{array}$ & $\begin{array}{l}\text { In the delivery process involving transportation activities may pose a } \\
\text { risk of accidents, vegetables, and reduced quality of vegetables during a } \\
\text { trip (due to rapid wilting) }\end{array}$ \\
\hline & R.3.2 & Demand changes & $\begin{array}{l}\text { Supplier receives orders through a PO (pre-order) were delivered every } \\
\text { day by the supermarket. }\end{array}$ \\
\hline & R.3.3 & Service level & $\begin{array}{l}\text { Assessment service level performed by supermarket retailers to assess } \\
\text { the performance of each supplier order fulfillment. }\end{array}$ \\
\hline & R.3.4 & Retour product & $\begin{array}{l}\text { There is a checker for vegetables delivered to the supermarket knows } \\
\text { that serves good quality vegetables. }\end{array}$ \\
\hline & R.3.5 & $\begin{array}{l}\text { Incomplete quality } \\
\text { control }\end{array}$ & $\begin{array}{l}\text { Tier suppliers have activity sorting, weighing, packaging, and shipping } \\
\text { of vegetables that should ensure the quality of vegetables in accordance } \\
\text { with the standards of the supermarket. }\end{array}$ \\
\hline
\end{tabular}


chain logistics costs vegetables is dominated by the cost of material handling $70.40 \%$ of the total cost of logistics. The next highest logistics costs of transportation for $19.69 \%$ of the total cost of logistics. In the third place cost components in each tier (Guritno $\left.{ }^{2}, 2013\right)$. At each tier in addition to calculating the mean, standard deviation, and variance calculation cost is also an upper limit and a lower limit as supporting data to show the

Table 5. Logistics cost structure of supply chain fresh vegetable

\begin{tabular}{|c|c|c|c|c|c|}
\hline \multirow{2}{*}{ Activity } & \multirow{2}{*}{ Cost Structure } & \multicolumn{3}{|c|}{ Logistics Cost (Rp/kg) } & \multirow{2}{*}{$\begin{array}{c}\text { \% Logistics } \\
\text { Cost }\end{array}$} \\
\hline & & Mean & Low & High & \\
\hline \multirow{3}{*}{ Procurement } & Transportation Cost & 80.13 & 0.00 & 562.00 & 3.42 \\
\hline & Communication & 12.33 & 0.00 & 69.44 & 0.53 \\
\hline & Total & 92.46 & 0.00 & 0.00 & 3.95 \\
\hline \multirow{6}{*}{$\begin{array}{l}\text { Material } \\
\text { handling }\end{array}$} & On-farm cost & 586.79 & 0.00 & 4917.98 & 25.06 \\
\hline & Post-harvest cost & 401.91 & 2.82 & 1738.59 & 17.16 \\
\hline & Inspection & 604.37 & 0.00 & 2976.19 & 25.81 \\
\hline & Depreciation & 54.00 & 0.00 & 273.99 & 2.31 \\
\hline & Losses & 1.33 & 0.00 & 4.84 & 0.06 \\
\hline & Total & 1648.39 & 0.00 & 0.00 & 70.40 \\
\hline \multirow{3}{*}{ Maintenance } & Maintenance of machine & 54.11 & 1.14 & 265.58 & 2.31 \\
\hline & Maintenance of trucks & 30.13 & 0.00 & 198.41 & 1.29 \\
\hline & Total & 84.24 & 0.00 & 0.00 & 3.60 \\
\hline Inventory & Holding cost & 28.58 & 0.00 & 174.60 & 1.22 \\
\hline \multirow{4}{*}{ Transportation } & Shipping & 413.98 & 0.00 & 1312.50 & 17.68 \\
\hline & Depreciation & 38.82 & 0.00 & 297.62 & 1.66 \\
\hline & Losses & 8.27 & 0.00 & 57.44 & 0.35 \\
\hline & Total & 461.08 & 0.00 & 0.00 & 19.69 \\
\hline Information & Communication & 26.85 & 0.00 & 101.31 & 1.15 \\
\hline \multicolumn{2}{|c|}{ Total logistics cost (Rp/ kg) } & 2341.61 & & & 100.00 \\
\hline
\end{tabular}

there are the logistics procurement costs amounted to $3.95 \%$ of the total cost of logistics. Then the next logistics costs, i.e. maintenance, inventory, information respectively have a percentage of $3.60 \%$, $1.22 \%$ and $1.15 \%$ of the total cost of logistics.

Table 5 shows the results of calculation of the mean, the upper limit and lower limit of each component of costs along the supply chain of vegetables. The mean calculation performed to demonstrate a representative of the overall values obtained costs. However, deviation calculations necessary to determine the diversity of the data so that the calculation of standard deviation and variance of costs on largest and smallest range of data on each component costs.

In Table 6 it can be seen that the tier suppliers dominate the overall cost of logistics activity. This is due, the supplier has a direct role to provide added value in the form of best quality vegetables to be sold in supermarkets. Besides good packaging will also add to the aesthetic and consumer confidence supermarket to buy vegetables at the supermarket. From Table 7, it can be seen that the most influential logistics activities at all tier supply chain is the vegetable material handling. At tier farmers, the cost of material handling is $96.09 \%$. This suggests that the cost

Table 6. The logistics cost percentage of each tier of fresh vegetable supply chain.

\begin{tabular}{|c|c|c|c|c|c|c|}
\hline Tier & $\begin{array}{c}\text { Procurement } \\
(\mathbf{\%})\end{array}$ & $\begin{array}{c}\text { M. Handling } \\
(\mathbf{\%})\end{array}$ & $\begin{array}{c}\text { Maintenance } \\
(\mathbf{\%})\end{array}$ & $\begin{array}{c}\text { Inventory } \\
(\mathbf{\%})\end{array}$ & $\begin{array}{c}\text { Transportation } \\
(\mathbf{\%})\end{array}$ & $\begin{array}{c}\text { Information } \\
(\mathbf{\%})\end{array}$ \\
\hline Farmer & 6.27 & 23.28 & 15.29 & 2.14 & 0.13 & 20.75 \\
\hline Collector & 15.08 & 14.16 & 11.91 & 10.65 & 27.13 & 34.42 \\
\hline Trader & 78.65 & 62.56 & 72.81 & 87.21 & 72.74 & 44.83 \\
\hline $\begin{array}{c}\text { Total } \\
\text { (\%) }\end{array}$ & $\mathbf{1 0 0 . 0 0}$ & $\mathbf{1 0 0 . 0 0}$ & $\mathbf{1 0 0 . 0 0}$ & $\mathbf{1 0 0 . 0 0}$ & $\mathbf{1 0 0 . 0 0}$ & $\mathbf{1 0 0 . 0 0}$ \\
\hline
\end{tabular}

Table 7. The percentage of logistics activities in each tier.

\begin{tabular}{|c|c|c|c|c|c|c|c|}
\hline Tier & $\begin{array}{c}\text { Procurement } \\
(\mathbf{\% )}\end{array}$ & $\begin{array}{c}\text { M. Handling } \\
\text { (\%) }\end{array}$ & $\begin{array}{c}\text { Maintenance } \\
\text { (\%) }\end{array}$ & $\begin{array}{c}\text { Inventory } \\
\mathbf{( \% )}\end{array}$ & $\begin{array}{c}\text { Transportation } \\
\mathbf{( \% )}\end{array}$ & $\begin{array}{c}\text { Information } \\
\text { (\%) }\end{array}$ & Total (\%) \\
\hline Farmer & 1.15 & 96.09 & 2.14 & 0.10 & 0.11 & 0.40 & 100.00 \\
\hline Collector & 3.20 & 67.39 & 1.93 & 0.58 & 26.14 & 0.77 & 100.00 \\
\hline Trader & 5.34 & 59.48 & 4.57 & 1.85 & 27.21 & 1.55 & 100.00 \\
\hline
\end{tabular}


of material handling have a great effect on the tier farmers. Material handling costs (material handling), the largest at the farmer is in charge while in the field (on-farm costs), which reached $\mathrm{Rp} 1466.97$ / $\mathrm{kg}$ of vegetables. Costs incurred in the current cost farmers in the field (on-farm costs) include the cost of seeds, fertilizers and insecticides.

\section{CONCLUSION}

Stages corn supply chain is dominated by the role of wholesalers in relation to the requirements and the reduction of mycotoxin hazard, but did not find any special requirements concerning the fungus, but is represented in refraction value in the form of price reductions due to imperfections of the product (dirt, mildew, drought, etc.). Mycotoxin the possible emergence of corn has been detected since the stages of drying cornfield, corn peeling, storage and packing. Tier risk mitigation on farmers with land use in the protective roof of vegetables, checking pests / plant diseases on a regular basis, doing proper land management, and use proper harvesting techniques. Risk mitigation on collectors tier and tier suppliers to make a deal pre-order through good communication, application of the contract of purchase and sale, arrangement of vegetables both in the closed box when shipping the vegetables.

\section{ACKNOWLEDGEMENTS}

This article have received financial support from PHK I-C from Food Science Department of Faculty of Agricultural Technology. I would like to thank to Megita Ryanjani Tanuputri and Nur Rahma Laila Rizki Fauziah who helped in data collection of this research.

\section{REFERENCE}

Fujianti R, Guritno AD, Suwondo E. 2012. Valuation of supply chain performance in fresh vegetables using the analytical hierarchy process (AHP) and supply chain operations references (SCOR). Proceedings of a Conference on the Development of National Competitiveness; 2011 Nov 1618; Yogyakarta. 434 p.

Guritno $^{1}$, AD, 2013. Manajemen Rantai Pasok (Supply Chain Management) Edisi ke 2. Yogyakarta: Penerbit Universitas Terbuka.
Guritno2, A.D. 2013. Development of supply chain risk management of fresh vegetables. Proceeding of Food Innovation Asia Conference 2013: Empowering SMEs through science and technology. Bangkok, Thailand.

Guritno, A.D., Suwondo, E. Yuliando, H., Ushada, M., and H. Murase. 2013. Development of drum-buffer-rope algorithm to control capacity constrained machine in a bioproduction system. Proceeding of the 2013 IFAC Bio-Robotics Conference, International Federation of Automatic Control. Osaka, Japan.

Jaffee, S., Siegel, P and Andrews, C. 2010. Rapid Agricultural Supply Chain Risk Assessment: A Conceptual Framework. Washington DC: The International Bank for Reconstruction and Development/ The World Bank.

Kusumaputri DA, Guritno AD, Suwondo E. 2012, Evaluation of inventory decision and inventory balance of fresh vegetables in several stages of supply chains. Proceedings of a Conference on the Development of National Competitiveness; 2011 Nov 16-18; Yogyakarta. 434 p.

Pishvaee, M.S., H. Basiri and M.S. Sajadieh. 2009. Supply Chain and Logistics in National, International and Governmental Environment; Chapter 4: National Logistic Costs. Springer-Verlag. Berlin.

Rahayu, E.S., S. Raharjo dan A.A. Rahmianna. 2003. Cemaran Aflatoksin pada Produksi Jagung di Daerah Jawa Timur. Agritech 23 (4) : 174-183.

Waters, D. 2007. Supply Chain Risk Management: Vulnerability and Resilience in Logistic. London. The Chartered Institute of Logistic and Transportation. 